\title{
Garlic Additive on the Properties of Natural Rubber Vulcanite
}

\author{
Akinyele S. A ${ }^{1}$ and Olumayede E. G ${ }^{2}$ \\ Department of Science Technology, Federal Polytechnic Ado Ekiti, Ekiti State, Nigeria \\ Liberal Study Department, Rufus Giwa Polytechnic Owo, Ondo State, Nigeria.
}

\begin{abstract}
The effects of garlic additive and part replacement of sulphur in the conventional curative systems (mercapto benzothiazole-sulphur) MBT/S, (cyclohexyl benzothiazole sulphenamide-sulphur) CBS/S, and semi$E V$ on the mechanical and cure properties of natural rubber compound have been studied. Results show that the addition of garlic powder at content less than or equal to 6pphr to the conventional MBT/S mix improves the tensile strength of natural rubber compound. Part replacement of sulphur with garlic powder in the conventional MBT/S system up to 2ppr also enhances the tensile strength of the compound of natural rubber. $M B T / S$ systems in which sulphur has been replaced with garlic up to a level of 1.5pphr show comparable reversion resistance, cure rate index and scorch resistance to the conventional MBT/S systems containing less or equal to 6ppr garlic

Addition of 2pphr powder to semi- EV system improves tensile strength, while tensile strength depresses on the addition of $2 p p h r$ garlic powder to the CBS/S system. It appears advantageous therefore to include garlic powder in the corresponding formulation of natural rubber compound.
\end{abstract}

\section{Introduction}

Sulphur has been found to be extremely useful in the rubber industry (Barbin and Rodges, 1994). Rhombic sulphur is the most common form of sulphur used in the rubber industry being soluble in natural rubber at level up to 2.0pphr. Also, other than normal factory hygiene and operational procedures, it does not require any special handling or storage. The properties of natural rubber cured with MBT/S and CBS/S have been studied extensively (Bristow, 1986; 1987; Bernad, et al 1985; Adeosun 2000).

During the process of vulcanization, some of the double bonds in the rubber chain open up and short chains of sulpur atoms become attached. This sulphur chain may then link on to a neighboring rubber chain, thus connecting the rubber chains themselves (Bauer, 1984) Crosslinking increase with increasing sulphur content in the mix up to 2.0pphr of sulphur.

Garlic (allium sativum), is a hardy perennial plant that belongs to the lily family. The chemistry of garlic is complex, with over a hundred different compounds that contribute to its effects. The most important unique feature is its high content of organo-sulphur substances such as water-soluble compounds including sallyl systeine and other sulphur amino acids. The high content of sulphur related compounds in garlic has aroused interest in its being evaluated as an additive in natural rubber. The effects of part replacement of sulphur in the conventional natural rubber curative systems with garlic powder on the cure and mechanical properties of natural rubber were examined on this study.

\section{Materials And Method}

Material

(i) The natural rubber in this work was a Nigerian Standard Rubber grade 10 (NSR10) produced at the Michelin, Plantation, Araromi-obu, Ondo State Nigeria.

(ii)

Garlic was purchased at the Erekesan Market, Ado-Ekiti, Nigeria.

\section{METHODOLOGY}

The garlic was crushed fresh in a grinder and sun dried for seven days. The proximate and the elemental analyses were carried out using standard methods (AOAC, 2005). The rubber was characterized in Michelin using muffle furnace, plasticity and plasticity retention index using the Wallace plastimeter, protein content using a Kjeldahl method and volatile matter using the drying oven at $100^{\circ} \mathrm{C}$ for 4 hours. These properties were determined using methods reported in Standard Malaysian Rubber (SMR)

\section{COMPOUNDING AND CURING}

Compounding formulation: These are as shown in Table 4

Mixing: A standard mixing procedure summarized in Table 5 (Bateman 1963, Adu, 1991) was used for each compounding batch. This was performed on a water-cooled two-roll laboratory mill. The times of milling of rubber during the incorporation of other compounding ingredients are as shown in the table. 
Curing: curing was done at $185^{\circ} \mathrm{C}$ using a Monsanto Rheometer model 100 in accordance with the method recommended and reported by the British Standard Organization (BSO No 903, 1969, 1971). Cure properties were evaluated from rheographs produced from the rheometer (Table 7).

\section{Determination of mechanical properties}

A rectangular mould was filled with compounded sample and the compound cured at $142^{\circ} \mathrm{C}$ for 35 minutes in hydraulic water, it was steam pressed. After dropping vulcanizate in chilled water, it was allowed to cool for 48 hours in the water before dumbbell shaped test pieces were cut for the determination of mechanical properties. The tensile stress properties were determined using a Universal Tensiometer 4301 following the methods recommended and reported by BSO No 903, 1971. The stress strain curves from the Instron machine provided values for tensile strength, modulus and elongation at break.

A resilience cuboid test piece was cured at $142^{\circ} \mathrm{C}$ in a hudraulic operated stem press for 35 minutes dropped in chilled water and allowed to cool for 48 hours in the water. The test piece was tested for resilience using a Wallance Croydon Tester (Kurata 1966) Table 6.

A circular test piece used for hardness measurement was cured at $152^{\circ} \mathrm{C}$ for 15 minutes, in an hydraulic operated steam press, dropped into chilled water and allowed to cool for 48 hours in the water. The test piece was then tested for hardness using a Rubber Hardness Tester BSO No. 903, 1995). Table 6.

\section{DATA ANALYSIS}

(a) Cross-link density was evaluated as the difference between maximum and minimum torque rise (Bristow, 1986).

(b) Hysteresis was evaluate as the reciprocal of resilience

(c) The method used by Bristow (1986) was adopted in which reversion resistance was evaluated as being equal to

Time to $5(10) \%$ decrease from maximum torque

Time t o $90(95) \%$ torque rise from minimum

$$
=\quad \underline{\mathrm{t}}_{\underline{5}}\left(\underline{\mathrm{t}}_{10}\right){ }_{\mathrm{t}_{95}\left(\mathrm{t}_{90}\right)}
$$

(d) Cure rate index was evaluated using the relation (A sarifar and Jain, 1999)

100

Cure time- scorch time or

$$
\frac{100}{t_{95-} t_{\mathrm{S} 2}}
$$

\section{Results And Discussion}

It is observed from Table 1 that garlic used contains $63.06 \%$ water close to the $60 \%$ reported for garlic by Zalejska-fiolka (2001). The content of the garlic used $(12.13 \%)$ is higher while carbohydrate content $(16.45 \%)$ is lower than the contents of $6.50 \%$ and $30.00 \%$ respectively reported by Zalejska-Fiolka while other elements show significant variation. The variation in both proximate and elemental composition of garlic (Table 2) might not be unconnected with the difference in geographical location of cultivation and agricultural practices. The natural rubber used contains $5.78 \%$ protein, $2.19 \%$ carbohydrate and ash $1.03 \%$ (Table 3 ). The major elements are potassium and manganese with traces of sodium, copper and iron.

Figure 1 depicts the tensile strength of the vulcanizates, which have parts of their sulphur contents replace with garlic powder. Table 6 contains data on elongation at break, hardness, resilience and hysteresis of the vulcqnizate. It is observed figure 1 that $\mathrm{CBS} / \mathrm{S}$ and semi-EV system shown comparable strength superior to that of the MBT/S system. On the whole replacement of sulphur with garlic powder in the system CBS/S, semiEV and MBT/S tensile strength deteriorated appreciably. All the free sulphur atoms have been replaced with associated sulphur atoms present in garlic. This has drastically reduced the cross-link density of the vulcanizates leading to depressed tensile strength. It is however interesting to note that on the replacement of only 5.0pphr with garlic powder, tensile strength improves. Tensile strength improves, reaches a maximum and then decreases with increasing garlic content in the vulcanizate. Vulcanizates containing up to 2.0pphr of garlic powder show superior strength to the conventional MBT/S vulcanizate. The conventional vulcanizate shows higher tensile strength compared to the MBT/S. vulcanizate. The conventional CBS/S vulcanizate shows higher tensile strength compared to the MBT/S vulcanizate containing garlic powder.

Elongation at break improves at the onset of part replacement of sulphur with garlic powder and increases with increasing garlic content in the vulcanizate garlic content in the vulcanizate. The MBT/S vulcanizate shows compatible hardness compared to $\mathrm{CBS} / \mathrm{S}$ vulcanizate, which is harder than semi-EV vulcanizate. On the whole replacement of sulphur with garlic in the conventional curative creates a general decrease in hardness for the MBT/S system, hardness decreases with increasing garlic powder additive in the mix. The conventional MBT, CBS and semi-EV systems show comparable scorch and cure times. On the replacement of sulphur with 2.5 and 1.6pphur garlic in the CBS and semi-EV systems respectively scorch time improves but systems cure at longer times. On the MBT system, part replacement of sulphur with garlic up to 
1.5pphur does not have significant effect on scorch and cure times. But at garlic content greater than $1.5 \mathrm{pphr}$ scorch improves and system cure at longer times.

Cross-link density evaluated as the difference between maximum and minimum torque shown a decreasing trend MBT, CBS and semi-EV (Table 7). on the replacement of sulphur with garlic in the CBS and semi-EV system, cross-link density depresses appreciably. For the MBT systems, though no consistent trend is observed, all systems containing garlic show depressed cross-link density compared to the convention MBTsulphur system. This implies that the C-S linkages in the sulphur are significantly more than that of garlic sample. The MBT, CBS, semi-EV and the MBT systems where sulphur has been replace with garlic up to 1.5pphur cure at comparable rate faster than the MBT system wit the whole sulphur replaced with garlic content more than .5pphr and CBS system with whole sulphur content replaced with garlic.

Figure 2 depicts the tensile strength of the vulcanizates in Table 4. It is observed that the conventional $\mathrm{CBS} / \mathrm{S}$ system shows comparable strength to that of the conventional semi-EV system. Both system show higher strength compared to the MBT/S system. On the addition of 2ppr garlic powder to each of the system, the $\mathrm{MBT} / \mathrm{S}$ and the semi-EV have their strength improved while CBS/S has its strength depressed.The strength of the MBT/S vulcanizates containaing varying contents of garlic improves with increasing garlic content to 6ppr and the decreases with garlic powder content. The enhancement of strength by garlic powder may be due to the fact that introduction of garlic powder (carbohydrate Polymer) into the rubber matrix resulted in polymerpolymer mix. The presence of such mixes has been known to have synergistic effects especially where both polymers are compatible (Billmeyer, 1971). The results of this work show that compatibility of carbohydrate and rubber polymers leads to the enhancement of tensile strength.

The CBS/S and MBT/S systems show comparable hardness (Table 7) superior to that of the semi-EV system. The same trend is observed for the MBT/S garlic, CBS/S garlic and the semi-EV systems with CBS/S $\mathrm{MBT} / \mathrm{S}$. MBT/S garlic shows comparable but superior hardness to semi-EV and semi EV/garlic systems whose level of hardness are comparable. Hardness decreases, reaches a minimum and thereafter increase with increasing garlic powder content in the MBT/S system. Though resilence seems not to show appreciable difference for the systems (Table 7), the CBS/S system shows a slightly better resilience than the other systems. Hysteresis values of all system are comparable with $\mathrm{CBS} / \mathrm{S}$ system having a slightly lower hysteric values. Garlic powder improves elongation at break.

The cure properties of the compounded systems in Tables 4 are depicted in Tables 7. The cure time of the MBT/S system has a value of 66 seconds. This value increases to 74.4 seconds on the introduction of $2 \mathrm{pphr}$ garlic powder and thereafter decreases progressively with increasing garlic content in the mix. MBT/S system containing garlic powder generally shows comparable cure times reasonably comparable to that of the MBT/S system without garlic $66 \pm 8$ secpnds). Garlic depresses the cure times of the CBS/S semi-EV systems. Garlic generally improves the scorch time of the conventional mixture MBT/S, MBT/S garlic,semi-EV garlic system. The cure rate index follows a similar trend to that followed by cure time. The practical implications of change in cure and scorch times is not the same. While high scorch time is an advantage which guarantees processing safety by resisting pre-vulcanization, high cure time is an economic disadvantage by way of increasing production cost requiring higher energy input for curing.

Cross-link density is higher for MBT/S system than for CBS/S and semi-EV system. Garlic powder generally reduces the cross-link density of he systems. This behavior has been explained in terms of reduced C-S linkages in such systems. The ability of MBT/S systems toresist reversion is to that of CBS/S and semi EV systems. Systems containing garlic less or equal to $6 \mathrm{pphr}$ show comparable reversion resistance higher than systems containing higher than 6ppr garlic powder.

\section{Conclusion}

Result show that part replacement of sulphur with garlic powder in the conventional MBT/S system up to $2 \mathrm{pphr}$ enhances the tensile strength of natural rubber vulcanizate. Also MBT/S systems composites in which sulphur has been replaced with garlic powder up to a level of $1.5 \mathrm{pphr}$ show comparable scorch time, cure time, cure rate index and reversion resistance to the conventional MBT/S system. It appears sulphur/garlic mix (at garlic content less or equal to $1.5 \mathrm{pphr}$ ) could be used in natural rubber for enhanced strength of vulcanizates.

It has been demonstrated that the addition of garlic powder at content less or equal to $6 \mathrm{pphr}$ to the conventional $\mathrm{MBT} / \mathrm{S}$ mix improves the tensile strength of natural rubber compound. Conventional MBT/S show comparable scorch time, cure time index and reversion resistance to the MBT/S mix containing less or equal to $6 \mathrm{pphr}$ garlic content. It seems advantageous, to include garlic at a level up to $6 \mathrm{pphr}$ as an additive in the formulation of natural rubber vulcanizate.

\section{Acknowledgement}

Thanks are due to the Management of Dunlop Nig. Plc Lagos and Michelin Plantations Araromi-Obu for laboratory facilities. 


\section{References}

[1]. AOAC: In official methods of Analysis, $14^{\text {th }}$ Edition. Washington D.C. 2005

[2]. Adeosun, B.F. Mechanical and Rheological Properties of natural rubber composites reinforced with agricultural waste, Nig. J. of Polymer Sci. and Tech. Vol. No 1, pp58-62, 2000.

[3]. Adu, O.E: Effects of fillers on mechanical and viscoelastic properties of cured rubber, M.Sc. Thesis, University of Benin, Nigeria. 1991.

[4]. Ansarifar, M.A. and Jain A.: "Optimising silences in silica filled rubber products, rubber Tech. Int. 34 pp 1-4 (1999).

[5]. Barbin W.W. and Rodgers M.B.: The science of rubber compounding in Science and Technology of rubber, Ed James R. Mark, Birak Brman and Fredric R. Eirich $2^{\text {nd }}$ Edition Academic Press Inc. Pub, 1994.

[6]. Bateman, L: The Chemistry and Physics of Rubber like substances Bateman, L. (Ed) Macleman, London, 1963.

[7]. Bauer, P.T.: The rubber industry. A study in competition and Monopoly. (Chap 17, the rise of synthetic rubber) Longman, London, 1948 .

[8]. Brostow, G.M.: Reversion Resistance of Accelerated sulphur systems. NR Technology Vol. 17 part 1, 7-17, 1986.

[9]. Billmeyer F.W.: Textbook of polymer Science $2^{\text {nd }}$ Edition, Wiley interscience, New York, chapter 3 (1971).

[10]. Brostow G.M.: Changes in Viscosity and cure behavior of Natural rubber compounds during storage at 20-40oC, NR Technology Vol. 18, part 2, 35-40, 1987.

[11]. British Standard Organisation (No 903, 1969, 1971, 1995). Testing procedures and standard in Rubber Technology and Manufacture, Ed. G.M. blow, $2^{\text {nd }}$ Edition (1975)

[12]. Kurata M. Viscosity Molecular weight relationship and uperturbed dimensions of linear chain molecules in Brandrup J. and immegut E.H (Eds) Polymer handbook, Iterscience Div. John Wiley and Sons, New York 72 (1966).

[13]. Standard Malaysian Rubber bulletin No. 7, RRIM test methods for Standard Malaysian Rubber Research institute of Malaya, Kualar Lumphur, 1970

[14]. Zalejska-Folka, J: The Influence of garlic extract on the oxidation process of edible oils, La Rivista delle sostanze Grasses Vol. Lxxxviii Guigno pp 343-346, 2001.

Table 1: Proximate Analysis of Garlic Additive

\begin{tabular}{|l|l|l|l|l|l|l|}
\hline & Water & Ash & Protein & Crude & Fat & Carbohydrate \\
\hline This work & 63.06 & 1.24 & 12.13 & 2.52 & 4.61 & 16.45 \\
\hline $\begin{array}{l}\text { Zalejska- } \\
\text { Folka }\end{array}$ & 60 & n.d & 6.5 & n.d & n.d & 30 \\
\hline
\end{tabular}

nd $=$ not determined

Table 2: Elemental Analysis of Garlic (mg/100g)

\begin{tabular}{|l|l|l|l|l|}
\hline & Iron & Magnesium & Potassium & Phosphorus \\
\hline This work & 1.68 & 17.87 & 16.58 & 7.71 \\
\hline Zalejska-Folka & 1.53 & 2.3 & 380 & 147 \\
\hline
\end{tabular}

Table 3: Proximate and Elemental Analyses of Natural Rubber

\begin{tabular}{|c|c|c|}
\hline Dirt Content & (\%w/w) “ & 0.08 \\
\hline Volatile matter & “ & 0.79 \\
\hline Ash Content & " & 1.03 \\
\hline Protein Content & “ & 5.78 \\
\hline Carbohydrates & (ppm) “ & 2.19 \\
\hline $\mathrm{Na}$ & “ & 48.0 \\
\hline $\mathrm{K}$ & “ & 231.4 \\
\hline $\mathrm{Mn}$ & “ & 498.3 \\
\hline $\mathrm{Cu}$ & & 36.7 \\
\hline $\mathrm{Fe}$ & & 29.9 \\
\hline
\end{tabular}

Table 4: Compound Formulation some of the Samples under Study

20

Natural

100

Rubber

Zine

5

Oxide

Stearic

Acid

$\operatorname{MBT}\left({ }^{\mathrm{a}}\right)$

CBS( $\left(^{b}\right)$

Sulphur

Garlic

Powder

Carbon

Black

$\begin{array}{lllllllllllllllllll}1 & 2 & 3 & 4 & 5 & 6 & 7 & 8 & 9 & 10 & 11 & 12 & 13 & 14 & 15 & 16 & 17 & 18 & 19\end{array}$

$\begin{array}{lllllllllllllllllll}100 & 100 & 100 & 100 & 100 & 100 & 100 & 100 & 100 & 100 & 100 & 100 & 100 & 100 & 100 & 100 & 100 & 100 & 100\end{array}$

$\begin{array}{lllllllllllllllllllllllll}5 & 5 & 5 & 5 & 5 & 5 & 5 & 5 & 5 & 5 & 5 & 5 & 5 & 5 & 5 & 5 & 5 & 5 & 5\end{array}$

$$
\begin{array}{lllllllllllllllllllllllll}
3 & 3 & 3 & 3 & 3 & 3 & 3 & 3 & 3 & 3 & 3 & 3 & 3 & 3 & 3 & 3 & 3 & 3 & 3 & 3
\end{array}
$$

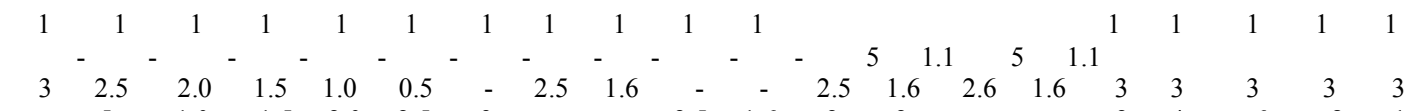

$\begin{array}{llllllllllllllllllllll}- & 5 & 1.0 & 1.5 & 2.0 & 2.5 & 3 & - & - & 2.5 & 1.6 & 2 & 2 & - & - & 2 & 4 & 6 & 8 & 10\end{array}$

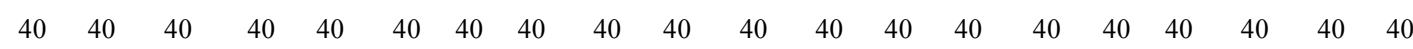


(a) Mercaptobenzothiazole accelerator

(b) Cyclohexphy benzothiazole sulphenamide accelerator

Table 5: Mixing Cycle

Maximum Temperature

Mixing Speed

Roll ratio (slow to fast)

Natural Rubber (NR)

$70^{\circ} \mathrm{C}$

$24 \mathrm{rpm}$

1 to 1.4

$60 \mathrm{sec}$

$\mathrm{NR}+2 / 3$ of carbon black

$60-120 \mathrm{sec}$

Incorporation of stearic acid and zinc oxide $120 \mathrm{sec}$

Incorporation of remaining $1 / 3$ of carbon black $\quad 30-60 \mathrm{sec}$

Incorporation of MBT, sulphur and garlic $240 \mathrm{sec}$

Total time (seconds)

$510-600 \mathrm{sec}$

Table 6: Effect of part replacement of sulphur with garlic powder on the mechanical properties of natural rubber samples in Table 4

Properties

$19 \quad 20$

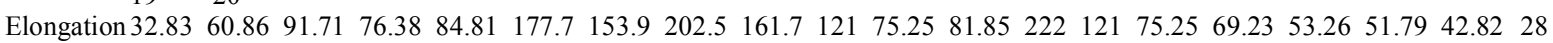
Break

(B) $\%$

$\begin{array}{lllllllllllllllllllllll}\text { Resilience } 52 & 54 & 54 & 54 & 53 & 56 & 62 & 57 & 60 & 54 & 52 & 53 & 53 & 54 & 52 & 52 & 53 & 51 & 50 & 53\end{array}$

$\begin{array}{lllllllllllllllllllll}\text { Hysteresis } & 1.92 & 1.85 & 1.85 & 1.85 & 1.89 & 1.79 & 1.61 & 1.76 & 1.67 & 1.85 & 1.92 & 1.89 & 1.89 & 1.85 & 1.92 & 1.92 & 89 & 1.96 & 2.0\end{array}$

1.1

$\begin{array}{llllllllllllllllll}\text { Hardness } & 81 & 81 & 77 & 76 & 73 & 70 & 54 & 63 & 80 & 74 & 80 & 73 & 80 & 74 & 80 & 77 & 75\end{array}$

7679

Black

Table 7: Effect of part replacement of sulphur with garlic powder on the cure properties of natural rubber sample1 Table 4

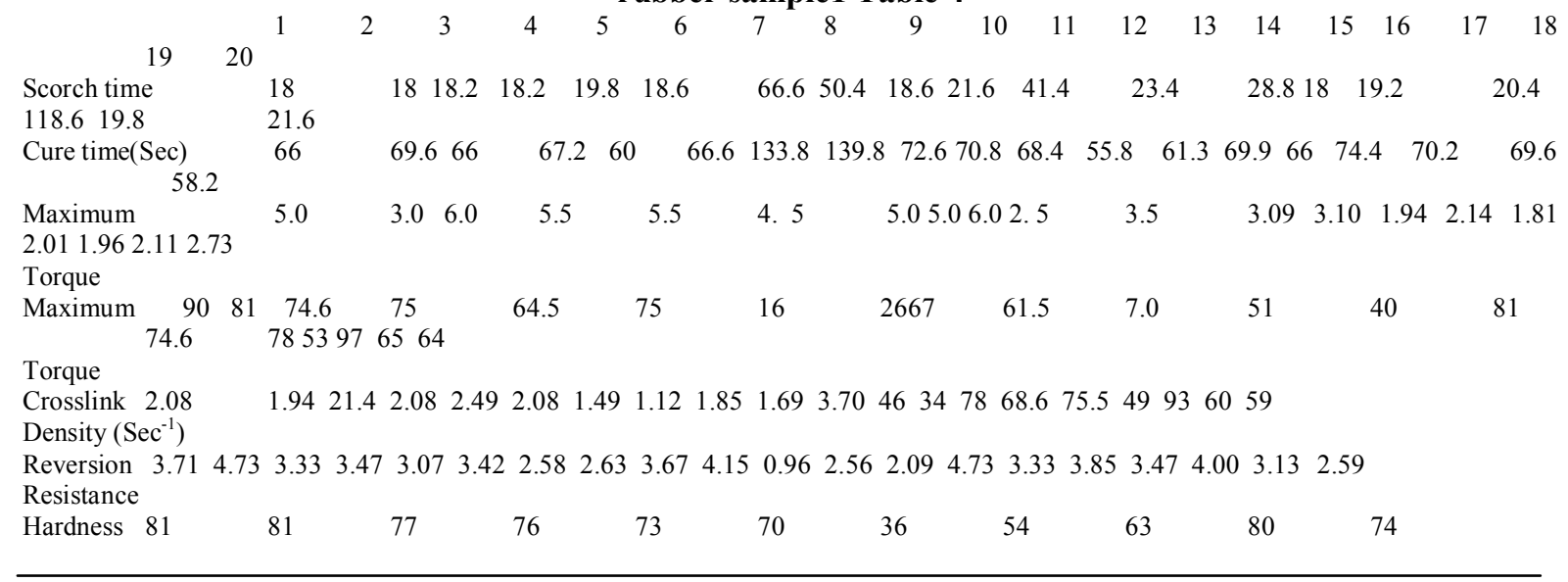

